\title{
Europe caught in innovation quagmire
}

Europe has a new plan to counter the worsening competitive position of its biopharmaceutical enterprises. But the scheme looks more tailored to meet the political aspirations of Brussels bureaucrats than to help the industry.

The policy is nominally based on a report submitted by Boston-based international consultancy Charles River Associates (CRA) to the European Commission last November, to investigate whether Europe's pharma and biotech industries were declining, and if so why. It showed the number of new drug approvals (NDAs) in Europe falling from 27 in 1999 to 17 in 2003, whereas the number of applications for NDAs dropped from nearly 40 in each of the years 2000 and 2001 to 25 in 2002 and 34 in 2003.

Although the US market experienced similar slips in NDA activity, it has also seen a much higher proportion of new biologics (monoclonal antibodies and recombinant proteins) coming on-stream. This is not happening in Europe, according to CRA's analysis. The effect is a divergence between the two regions not just in terms of innovation, but in revenues: the new generation of biotherapeutics are much more likely to be profitable than oldstyle, small-molecule drugs (Nat. Biotechnol. 23, 906, 2005).

"The decline is real and is likely to get worse," noted independent biotech consultant David Glover, former research director of Cambridge Antibody Technology. Many young European firms, he said, are becoming disillusioned with the lack of reward for innovation. "They are voting with their feet, and either leaving Europe or being acquired." Nor does the overall trend in R\&D spending in Europe, which in 2003 stood at $1.93 \%$ of Gross Domestic Product (versus $2.6 \%$ in the US and 3.15\% in Japan), offer solace.

After digesting the CRA report, the commission ran a public consultation with interest groups, including the private sector, to investigate possible remedial actions across the pharma and biotech industries. European Commission vice-president Gunter Verheugen accordingly announced a policy during the summer. One component is already in place-a doubling of financial support for life sciences research, taken from the six-year, $€ 73(\$ 132)$ billion Research Framework Program that begins in 2007. Second is a plan to grease the wheels of safety and efficacy testing for new types of medicines-with Verheugen emphasizing in particular the importance of identifying and validating biomarkers as a means of evaluating efficacy.

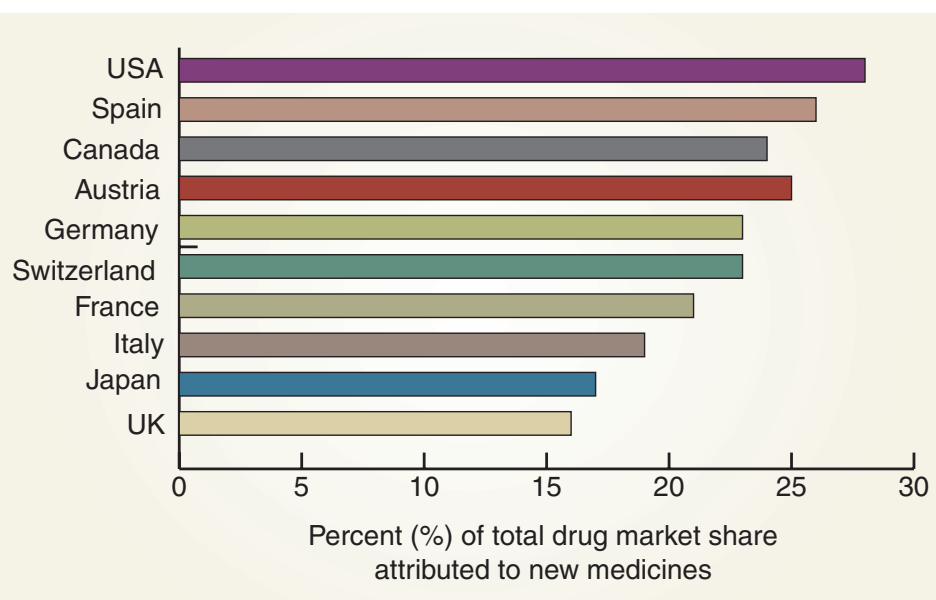

EU countries, most notably the UK, are lagging in innovation, as shown by the market share captured by new medicines in various countries in 2003, including all products launched between 1997 and 2002 into primary-care and hospital markets. Source: Association of the B ritish Pharmaceutical Industry, based on data from IMS World Review.

A third component of the strategy will be to resolve the patchwork of different national systems for drug pricing, which "place a significant burden on industry and can delay access to the market." Fourth, the restrictions on patient access to information on new medicines are to be reconsidered.

Verheugen is confident the program will deliver some concrete results within three years. But aside from the focus on price controls, his proposals bear little relation to what industry regards as the real problem.

And that is money. The pharma industry's biggest source of new blockbuster products-and new revenues-is biotech. Most of these products originate from relatively young companies, and Europe has been far poorer at sustaining these firms than has the US because the cash needed to run large-scale clinical trials is not available. Startups often run out of financial runway after three to five years, just when they ought to be taking off.

"If there is one thing that hampers Europe, it's the lack of capital," said Aisling Burnand, chief executive of the UK-based Biotechnology Industry Association. "US companies can raise significantly larger amounts of capital than their European counterparts at every stage." She claims a six- to ten-year-old company in the US can raise 16 times more money than one in Europe. "That allows them to fund their pipelines and also have quite large sums to make strategic acquisitions and grow their organizations."

Glover's diagnosis is similar. "Most European companies lack critical mass," he said. "They have less cash, and there is an issue with the unsophisticated investment climate and community in Europe."

Yet the commission's strategy glosses over this crucial point. Plus, although it is true that the commission is promising to address the pricing problem, its suggestion-to persuade member states to accept a common drug pricing system-is pure pie in the sky. No European country will consider giving up control over its healthcare budget to satisfy the commission's desire for a competitive drugs industry - a fact admitted to even by the commission itself. "Given the importance and sensitive nature of this issue, it is clear that we will not be able to make quick progress," said Verheugen.

No one denies that Europe's problems have multiple causes, calling for a battery of measures. But politics dictates that the commission sees pan-European regulation as the one and only solution to every problem, although individual countries rarely agree with it.

This conflict has wrecked a good many of the commission's schemes. The EU clinical trials directive, described by Glover as a "debacle," followed the usual pattern whereby member states pay lip service to the commission's policies while ignoring them wherever they prove inconvenient to national self interest. Other spectacular misplays include the genetically modified crop fiasco and the ill-fated European Constitution. The commission's plan to promote innovation could founder on the same rocks.

Peter Mitchell, London 